\title{
Different Approaches and Techniques on Reconstruction
}

\author{
Mustafa Gunay \\ Istanbul Gelisim University, Istanbul / Turkey \\ E-mail: mgunay@gelisim.edu.tr
}

\begin{abstract}
Reproduction; it is a form of obtaining a new production as a result of quoting and imitating a previous work. On the basis of the word production; It refers to the process of the products that arise as a result of the joint functioning of the substances that exist in nature and the labor of human beings until they reach the result. In other words, production; It refers to the entire process of raw material, labor, time and effort until the resulting product reaches a result.

Within the scope of this study, it is aimed to reveal that the concept of reproduction is a method frequently used by photographers in the production processes of artists. Approaches and methods developed in reproduction in photography will be examined. Reproduction of different art disciplines such as painting and cinema will be emphasized.
\end{abstract}

Keywords: Photography, Reproduction, Different Approaches, Techniques

DOI: $10.7176 /$ JSTR/6-02-02

\section{Fotoğrafta Yeniden Üretim Olgusu Üzerine Farklı Yaklașımlar ve Teknikler}

\begin{abstract}
Özet
Yeniden üretim; daha önceden yapılmış bir çalışmanın alıntılanması, taklit edilmesi sonucu yeni bir üretim elde etme biçimidir. Üretim kelimesi temelinde; doğada var olan maddeler ile insanoğlunun emeğinin ortak işleyişi sonucu ortaya çıkan ürünlerin, sonuca ulaşana kadar geçirdiği süreci ifade eder. Başka bir deyişle üretim; hammadde, emek, zaman ve mesainin ortaya çıkan ürünün sonuca ulaşana dek geçirdiği sürecin tamamını işaret eder.

$\mathrm{Bu}$ çalışma kapsamında yeniden üretim kavramının fotoğraf sanatında, sanatçıların üretim süreçlerinde sıklıkla başvurdukları bir yöntem olduğunu ortaya koymak amaçlanmaktadır. Fotoğrafta yeniden üretim içerisinde geliştirilen yaklaşımlar ve yöntemler incelenecektir. Fotoğrafin kendine konu aldığ 1 resim, sinema gibi farklı sanat disiplinlerinin yeniden üretimi üzerinde durulacaktır.
\end{abstract}

Anahtar Sözcükler: Fotoğraf, Yeniden Üretim, Farklı Yaklaşımlar, Teknikler

\section{Giriş}

19. Yüzyılda pozitif bilimlerin öne çıkması, teknolojik gelişmeler ve fotoğraf ile görünen gerçeğin yakalanması yepyeni bir görme biçimini ortaya çıkarmış, dünyaya daha farklı bir gözlem ile bakılmaya başlanmıştır. Bunun sonucunda fotoğraf en başta resim sanatı ile görme konusunda büyük bir paralellik göstermektedir. İcat edildiği ilk günden başlayarak fotoğraf; resim sanatında kendine önemli bir yer edinmiş, resmin fotoğraftan etkilendiği gibi fotoğrafta resim sanatından etkilenmiştir.

İcadı ve gelişimini takip eden yıllarla birlikte fotoğrafın kullanım alanlarında farklı teknikler ortaya çıkmıştır. Sanat dallarının çoğunda kendine yer bulan fotoğraf, bu sanat dallarından hem etkilenmiş hem de etkilemiştir. Bir sanat dalı olarak ortaya çıkışı ve sanat disiplinleri arasında olan etkileşimi fotoğraf popüler bir disiplin yapmaktadır. 19. yüzyıl boyunca resim ile ilişkilendirilen fotoğrafı o dönem içerisinde değerlendirdiğimizde en etkili olduğu alan resim sanatı ve ressamlar olmuştur.

Fotoğrafin resimde etkilerinin ilk görülmeye başlanılıp ifade edilişi izlenimciliğin etkileri ile meydana gelmiştir. Fotoğrafçılık içerisinde İzlenimciliğin en temel bakış açısı olan doğayı olduğu gibi yorumlamak yerine kişide bıraktığı izlerle tekrar yorumlanması şeklinde olmuştur. Fotoğrafın resim 
sanatına açtığı en önemli yol, fotoğraf gibi bir görmeve aktarma sanatı değil de bir algılama sanatı olmayı hedeflemesidir. Bu çizgide devam edip yaratma sürecini aktif olarak kullanması, resimde algılanan gerçeği ifade eden kişi durumuna getirmeyi başarmış olan fotoğrafin teknik gelişmeleri olmuştur.

Fotoğraf ile birlikte sanatçının görüş açısı değişmiş ve ayrıca sanat ile ilgilenen insanların bakış açısı da değişime uğramıştır. Bir fotoğrafin çekilme biçimi fotoğraf makinesinin arkasındaki kişiye bağlıdır. Kadraj ve aydınlatma, fotoğrafçının bir nesnedeki ayrıntıları vurgulama biçimi fotoğraftaki tüm değerleri farklılaştırabilir. Bu bağlamda fotoğrafik görüntü ile resim arasındaki etkileşimin fotoğrafçı ve ressam arasında gerçekleşen yaratı süreciyle şekillendiği görülmektedir.

Yeniden fotoğraflama eylemi orjinalitenin anlamsızlığını ve gereksizliğini savunan görüşü destekleyen bir sanatsal tekniktir. Postmodern fotoğraf anlayışının en önemli kısmını kapsayan yeniden fotoğraflama eylemi postmodernistlere göre yeni bir görüntü üretebilmenin hemen hemen tek yoludur. Bu bağlamda herhangi bir şeyi "yeni" yapmanın yolu onu yeniden yapmaktan geçmektedir. Yeniden fotoğraflama eylemi ise postmodern fotoğraf anlayışının temelini oluşturan "kendine mal etme" kavramını doğurmaktadır.

Postmodernist söylem pek çok sanat disiplininde kendini göstermiş, akademilerin hemen hemen her köşesinden fişkırmışıtır ancak fotoğraf; yeniden üretimi temel alan postmodernizm için en verimli alan olmuştur. Yeniden üretim, kendine mal etme, çoğulcu söylem ve aşırma olgularılyla fotoğraf adeta postmodernist bayrağ kale burcuna diken güç konuma erişmiştir. Eser sahipliği ve sanatçı kavramlarını topa tutan postmodern felsefe de fotoğrafin kimlik arayışı sorununa yepyeni bir boyut kazandırmıştır. $\mathrm{Bu}$ noktada fotoğrafin "sanat olma" kavgası da anlamını yitirir.

\section{Yeniden Üretim Ve Fotoğrafta Yeniden Üretim Kavramı}

$\mathrm{Bu}$ bölümde öncelikli olarak çalışmanın ana hattını oluşturan yeniden üretim kavramının genel tanımlamaları ve diğer olgular ile ilişkileri belirtilecektir. Ardından asıl çalışma konusu olan fotoğrafta yeniden üretim kavramlarının açıklamalarına yer verilecektir.

\subsection{Yeniden Üretim Kavramı}

Yeniden üretim kavramı, çağımızda oldukça geniş bir sahanlıkta kendisini tanımlamaktadır. Yeniden üretim denildiğinde var olan bir nesnenin, tüm bileşenlerine ayrıllp tekrar birleştirilmesi sürecinde yeni özelliklerle donanması ve yeni işlevlere sahip olması anlaşılmaktadır. Genel tanımı içerisinde yeniden üretim kavramı ekonomik bir sürdürülebilirlik düşüncesi ile ilişkili olarak ön plana çıkmaktadır. Yeniden üretim süreci üç aşamaya ayrılmaktadır:

- Ayrıştırma: Ürünlerin tamamen bileşenlerine ayrılması aşaması.

- Yeniden üretim: Ürün ve parçaların yeni ürünler için gerekli koşullara kavuşturulmak üzere işlenmesi aşaması.

- Yeniden montaj: Yeniden üretilen parçaların ve gerektiğinde yeni parçaların monte edilerek son ürün haline getirildiği aşama (Topoyan, 2005).

Yukarıda yer alan bu üç aşama göstermektedir ki, endüstriyel anlamda yeniden üretim; eski ürünün değerlendirilmesi ve yenilenmesi esası ile olmaktadır.

Yeniden üretim; daha önceden yapılmış bir çalışmanın alıntılanması, taklit edilmesi sonucu yeni bir üretim elde etme biçimidir. Göstergeler arasılık kavramının, metinler arasılık kavramına karşı geldiği gibi yeniden üretim kavramı da yeniden yazma kavramına karşıllk gelmektedir.

Julia Kristeva yeniden yazma kavramını "farklı gösteren dizgelerini yeniden dağıtmak, yeni bir metin buna bağlı olarak da yeni anlamlar üretmek" olarak tanımlamaktadır.

Kubilay Aktulum ise daha detaylı bir tanımlama yaparak; "Metinler arası ilişkiler bağlamında bir yöntem olarak anılan yeniden yazma, bir yazarın başka bir yazara ait bir metni, bir gönderge metnini, bir alt metni yeniden yazması, onu yeni bir durumda, yeni bir bağlamda, yeni bir okur kitlesi için, yeni işlevlerle yeni erkelere dönüştürmesi işlemi” olarak tanımlamaktadır (Aktulum, 2011:149).

Yeniden yazma genel olarak, hangi türde olursa olsun önceki bir metnin, onu taklit eden, dönüştüren, açık ya da kapalı bir biçimde ona gönderen bir başka metinde yinelenmesi olarak tanımlanmaktadır (Aktulum, 2011:236).

Yeniden yazma ile ilgili bu tanımlamalar aynı zamanda yeniden üretim kavramı içinde kullanabilmektedir. Birisi sözsel olanı temel alırken diğeri sözsel olmayanı temel almaktadır. Yeniden üretim zamanın akışına bağlı olarak farklı bakış açılarını da beraberinde getirmektedir. Yeniden üretim işlemi bir sanat eserine yeni bir açıdan bakma olanağı sağlamaktadır ve yeniden üretilen eserin yeni bir gözle değerlendirilmesinin önünü açmaktadır. Yeniden üretim ile birlikte geçmiş dönemlere ait eserler alıntılanarak yeni bir forma uygulanabilmekte, eserin özellikleri yeni bir anlama dönüştürülebilmektedir. 


\subsection{Fotoğrafta Yeniden Üretim}

20. yüzyıl sanatında bütün sanat dalları arasında bir ilişki söz konusudur ve bu ilişki, farklı sanat alanlarında kullanılan teknikler yoluyla her bir sanat alanının gelişimini ve birbirleriyle olan ilişkisini doğrudan etkilemektedir. Bu disiplinler arası çalışma ortamında fotoğrafta resim, grafik, edebiyat, heykel, tiyatro ve sinema gibi sanatlarla, yeni süreçte karş1lıklı bir etkileşim halindedir. Bu etkileşimin bir sonucu olarak yeniden üretim, diğer sanat dallarında olduğu gibi fotoğrafta da varlığını sürdürmektedir. Fotoğrafta yeniden üretimin geçmişine bakıldığında fotoğrafin resme hizmet ettiği kadar resmin de fotoğrafa konu olduğunu, birçok tablonun fotoğraf tarihinde fotoğrafçılar tarafından tekrar üretildiği görülmektedir.

19. yüzyılın ikinci yarısından itibaren hızla gelişen teknoloji, geniş halk kitlelerini endüstri merkezlerine toplayarak yeni toplum biçiminin ortaya çıkmasını sağlamıştır. Toplumsal değişimler, sosyal, kültürel gelişmeler ve teknik ilerlemeler, sanat alanındaki yenilikler fotoğraf sanatını da etkilemiştir. Bu etkileşim, fotoğrafın türlerini, konularını ve tekniklerini değişime uğratmıştır. Fotoğrafta uygulanan teknik ve estetik amaçlı müdahale yöntemleri fotoğrafin kendine özgü dilinin oluşmasını sağlamıştır. Böylece anlatım olanaklarının sınırsızlığının da farkına varılmıştır.

$\mathrm{Bu}$ bağlamda görüyoruz ki artık sanat dalları arasındaki sınırlar giderek yok olmaya başlamış ve aynı zamanda farklı sanat dallarının kaynaşmasından da yeni sanat alanları ortaya çıkmıştır. Fakat fotoğraf, sadece mekanik ve teknik bir işlem değildir, bütün bunların ötesinde diğer sanat dallarıyla bütünleşmeye en yatkın etkinliklerden birisidir. Fotoğrafa uygulanan müdahale burada rötuş, zihinsel ve estetik kaygılarla yapılan çalışmaların bütününe karşılık gelecek şekilde ele alınmaktadır. Diğer sanat dalları arasında bir ilişski vardır ve bu ilişki, farklı sanat dalları içerinde kullanılan teknikler yoluyla her bir sanat dalının gelişimini, yaratılan eserleri ve birbirleri arasındaki bağları etkilemektedir.

Victoria dönemi ressamları fotoğrafta elde edilebilen ayrıntıdan etkilenip bu ayrıntıları resimlerinde kullanırken, fotoğrafçılarda resimlerin içeriğinden etkilenmiştir. Henry Peach Robinson'un "The Lady of Shalott" fotoğrafi, Millais'in "Ophelia" tablosu ile karşılaştırıldığında, "Ophelia" tablosunun 9 sene önce yapıldığı görülmektedir.

Henry Peach Robinson, ressam John Millias'ın “Ophelia'nın Ölümü” adlı resmindeki görüntüyü kendi bakış açısıyla yeniden yorumlamıştır. Robinson'un yeniden ürettiği Ophelia'da sanatçı, biçimsel ve içeriksel olarak orjinal tabloya sadık kalmayı tercih etmiştir.

High Art etkisinde Shakespare eserlerini fotoğrafına konu alan bir diğer fotoğrafçı Julia Margaret Cameron'dur. Cameron, “Ophelia” fotoğrafını Robinson'un aksine doğa yerine stüdyoda kurgulayarak çekmiştir. Yine Robinson'un biçimsel ve içeriksel olarak orjinal tabloya sadık kalmayı tercih etmesinin aksine tabloyu yeniden yorumlamıştır.

19. yüzyılda fotoğrafta bir diğer yeniden üretim örnekleri olarak kendi içinde yeniden üretimine olanak sağlayan fotomontaj çalışmalarına rastlanmaktadır. Fakat bu dönemde bu çalışmalar çoklu baskı olarak isimlendirilmiştir. Çoklu baskı işlemi, birden fazla negatifin birleştirilmesinden oluşturulmaktadır. Fotomontaj, ilk olarak, 1928 yılında, kendisi de bir fotomontaj sanatçısı olan, Stepanova tarafindan tanımlanmıştır. Bu tanıma göre fotomontaj, "her biri, ayrı bir anlatım gücüne sahip anlık görüntülerin, tek bir fotoğraf üzerindeki birleşimi ve bileşkesidir.” 20. yüzyılda değişen sanat anlayışı ile birlikte üretilen fotomontaj çalışmaları da farklılaşmaya ve yeni sanat anlayışlarını destekleyen görüntüler olarak boy göstermeye başlamıştır.

Berlin'de 1920’de açılan Birinci Uluslararası Dada Fuarı Höch'ün “Yemek Bıçağı Dada Almanya'nın Bira Göbekli Weimar Kültür Çağını Kesiyor” başlıklı fotomontajı da yer almıştır. O dönem yazılan eleştirilerde, fuarda en çok ilgi gören eserin dönemin kültürel politikası çerçevesinde zengin okumalara kapı açtı̆̆ 1 için bu eser olduğu belirtilmektedir.

20. yüzyılın ikinci yarısına bakıldığında modernizmden postmodernizme geçişle birlikte bir fotoğrafın yeniden üretilmesi ya da başka bir sanat yapıtının fotoğrafla teknik ve içerik olarak yeniden üretilmesinin yanı sıra gerçekliğin yeniden üretimi kavramı karşımıza çıkmaktadır.

Postmodernizm, orjinal sanat yapıtını yeniden ele alma konusunda özellikle "temsilin temsili" kavramı üzerinde durmakta ve bu da fotoğrafın yeniden üretme olanağı ile ortaya konmaktadır. Bu açıdan fotoğraf postmodernizm içindeki yerini bu şekilde belirlemekte ve amaçlandığı gibi özgün eser kavramından uzaklaşmaya yardımcı olmaktadır. Fotoğrafın, bir olayın şahitliği işlevi artık tamamen geçersiz bir hal almaya başlamıştır. Bu dönemde fotoğrafik üretimin orijinalliğinin yıkılması sonucunda, sanatın yalnızca yinelemeye dayalı bir etkinlik olabileceği görüşü ileri sürülmüştür. Fotoğraf ürünleri özellikle gerçekliğin yeniden üretilmesiyle varlığını göstermektedir.

Fotoğraf eleştirmeni Andy Grundberg bu konuda görüşlerini şu şekilde belirtmiştir: "Fotoğraflar o karanlığa doğru sessizce yol alırken, görsel dünyanın nesneleri ve özneleri olma işlevini sürdürmektedir. Fotoğraflar bu işlevlerini, betimleyicilik, nesnellik, netlik, sabitlik, tekillik gibi modernistlere hitap eden özellikleri temel alarak değil; dolaylı anlatım, basmakalıplık, fazlalık, aşırılık, gizem gibi postmodernist

15 | P a g e

www.iiste.org 
özellikleri temel alarak yerine getirmektedir. Bu açıdan fotoğraf, son dönemde yeniden tanımlanmıştır" (Grundberg, 2002:119).

20. yüzyılın ikinci yarısında postmodernizme geçişle sanatta var olan tüm bu dönüşümlerin yanı sıra fotoğrafta yeniden üretim içerisinde yer alan yeni bir yaklaşım ortaya çıkmışıtır. Bu yaklaşım kendine mal etmedir. Sanatta kendine mal etme var olan objeleri ya da görüntüleri küçük değişikler yaparak ya da olduğu gibi kullanarak yeniden anlamlandırıp yeni bir forma sokmak, yeni bir sanat ürünü ortaya çıkarmak demektir. Fotoğrafta kendine mal etme eylemi, görüntüyü ait olduğu bir çevreden ve içinde bulunduğu koşullardan kopararak başka bir anlam kazanacağı farklı bir çevreye taşımaktadır.

Millias’ı “Ophelia'nın Ölümü” tablosu 21. yüzyılda da yeniden üretilmiştir. Fotoğraflarında sinema estetiğini kullanan Gregory Crewdson kendi tarzıyla Millias'ın “Ophelia'nın Ölümü” tablosuna fotoğrafla ve güncel teknoloji imkanları ile farklı bir şekilde yeniden yorumlamıştır.

Michelangelo'nun "Pieta" çalışmasını yeniden yorumlayarak üreten David La Chapelle çalışmasında bu eseri yeniden üreterek heykel ve fotoğraf arasında disiplinlerarası alışverişinde güzel bir örneğini günümüze kazandırmıştır.

\section{Fotoğrafta Yeniden Üretim İçerisinde Yer Alan Farklı Yaklaşımlar}

21. yüzy1la gelindiğinde dijitalleşmeyle birlikte geçmişte var olan tüm yeniden üretim yaklaşımları ve teknikleri postmodernist bir yaklaşımla birlikte daha da gelişip yaygınlaşmaktadır. Dijitalleşme ile fotomontaj tekniği bilgisayar ortamında üretilme firsatı bulmakta, geçmişin farklı sanat dallarındaki kült eserleri bugünün sanatında da hala konu edildiği gözlemlenmektedir. Fotoğraf farklı sanat dallarının yanı sıra masal ve mitlerinde yeniden üretilmesine olanak sağlamaktadır. Günümüzde teknik yöntemlerin yanı sıra yeniden üretim içerisinde; alıntı, parodi, pastij, kendine mal etme ve gizli alıntı kavramları da farklı yaklaşımlar olarak ele alınmaktadır.

\subsection{Alıntı}

"Bir metnin başka bir metinde ki varlığını en somut biçimde görünür kılan alıntı biçimli, istemli bir anımsamadır. Başka bir metine ait bir kesit yeni bir metine sokularak ona yeni bir anlam yüklenir. Bir söylem biriminin başka bir söylemde yenilenmesi olan alıntı ile yalın bir söylemler arası ilişki kurulur" (Aktulum, 2011:416).

Alıntı, günümüz sanatçıları tarafindan oldukça sıklıkla başvurulan yöntemlerden birisi olmuştur. Günümüz sanatçıları geçmiş, dönem sanatçılarının yapıtlarından kesitler ya da tamamıyla alıntılar yaparak hem geçmiş ve günümüzü birleştirmekteler hem de aynı esere farklı bakış açıları kazandırabilmektedirler. Bu yönüyle de alıntı, göstergeler arası alışverişlerde en fazla başvurulan yöntemlerden birisi olmaktadır. "Alıntının en temel özelliklerinden birisi devingen olmasıdır. Yani eski bilgileri harekete geçirerek yazınsal ya da resimsel bir mirası yeniden güncellemesidir" (Aktulum, 2011:44).

Öte yandan Compagnon ise "alıntının bir yineleme işlemi değil, yeniden sözceleme edimi olduğunu savunmaktadır. Yani alıntılanan kesit yeni bir bağlama sokularak anlamsal olarak dönüşmektedir. Dönüştürülürken de anlamsal ve bağlamsal bir dönüşüm söz konusu olmaktadır” (Aktulum, 2011:95). Özetle alıntı, iki yapıt arasında ilişki kurulması sonucu varolan bir esere yeni bir anlam katılarak yeni bir çalışma üretilmesidir. Alıntı, iki çalışma arasında ilişsi kurmasının yanı sıra farklı sanat disiplinlerinin birbirleri ile etkileşimlerine ve var olan çalışmaların yeniden üretilmesine olanak sağlamaktadır.

Alıntı, fotoğrafta yeniden üretim içerisinde en çok benimsenen yaklaşım biçimlerinden birisidir. 19 . Yüzyıldan itibaren birçok fotoğrafçının çalışmalarında ressamların tablolarından, yazarların eserlerinden ve tiyatro oyunlarından alıntılar yaptığı görülmektedir. Fotoğrafçılar çalışmalarında alıntı yaparken bir başka eseri birebir tekrarlayabilir ya da bir eserden kesitler alarak yeni çalışmalar üretebilir. Bunun yanısıra varolan çalışmaların yeniden yorumlanarak üretilmesi de alıntı yapılırken kullanılan bir diğer yöntemdir. Fotoğraf tarihinde erken dönemden günümüze kadar fotoğraf ve resim sanatları birbirini beslemiştir. Resim ve fotoğraf ilişkisini Roland Barthes "Camera Lucida" (1992) adlı kitabında şu şekilde belirtmiştir: “... İlk fotoğrafi gören ilk insan bunun bir resim olduğunu düşünmüşs olmalı: aynı çerçeveleme, aynı perspektif. Fotoğraf her zaman resim hayaletinden işkence görmüştür, hala da görmektedir; sanki tuvalden doğmuş gibi, kopyaları ve yarışıla resmi mutlak ve babadan kalma bir gönderme haline getirmiştir..."

Alıntı kapsamında bir diğer örnek ise yine sanat tarihinin başyapıtlarından birisi olan ve çok sayıda sanatçı tarafından yeniden üretilen Leonardo Da Vinci'nin, "Son Akşam Yemeğì" adlı eseridir. Eserde, İsa'nın çarmıha gerilmeden önceki akşam havarileriyle birlikte yediği son yemek konu alınmaktadır. Birçok fotoğrafçı resim karesini, fotoğraf karesine uyarlayarak belli bir eleştirel ya da kurgusal çalışma kapsamında resmi alıntılamıştır. Resmin, alıntı yöntemiyle fotoğraf olarak en çok kullanıldığı alanlardan birisi de televizyon dizilerinin tanıtım fotoğrafları için yapılan çalışmalardır.

16 | P a g e 


\subsection{Pastiş}

Pastiş, yeniden üretim içerisinde yer alan bir başka yaklaşımdır. Kubilay Aktulum; pastişi, tam olarak bir yapıtın değil, biçemin taklit edilmesi olarak tanımlamaktadır. Bir başka deyişle bir yapıtın biçemi ya da anlatım biçimi dolaylı olarak taklit edilmektedir. Eczacıbaşı sanat ansiklopedisi ise pastişi; "ünlü sanat yapıtlarının çeşitli bölümleri kopya edilerek, bütünlük kaygısı güdülmeden bir araya getirilmesiyle oluşturulan eklektik yapıt olarak tanımlamaktadır (Eczacıbaşı, 1997:1435).

Daha genel bir tanımlama ile pastiş, bir sanatçının yapıtının, başka bir sanatçı tarafından üslubu, içeriği, kapsamı ve dilinin taklit edilmesi ile gerçekleşmektedir. Böylece çalışmada taklit üzerinden anlam kurulmaktadır. Sanat yapıtlarının, yeniden üretilebilmelerinin bir sonucu olarak, geçmiş dönem eserleri birçok sanatçı tarafından farklı yöntemlerle ele alınarak güncellenmektedir. Hemen hemen her dönemde pasties başvuran ve hayranlık duydukları birçok sanatçının eserlerinden ilham alarak benzerini yapan birçok sanatçıya rastlamak oldukça mümkündür. Birçok farklı sanat disiplinine ait yapıtlar, pastişe bağ lı olarak kopyalanmaktadır. Bu kopyalama işlemine bağlı olarak da geçmiş dönem sanatçılarının eserlerinden beslenen birçok çağdaş sanatçı yeni eserler meydana getirmektedirler.

Pastiş bağlamında ele alınabilecek en önemli örnek resim tarihinde birçok ressama ilham kaynağı olan ve defalarca farklı düzenlemeleri yapılan, ilk olarak İtalyan Rönesans dönemi ressamlarından Giorgione'nın yaptığı ve "Uyuyan Venüs" adını verdiği çalışmasıdır.

Giorgione'nin bu çalışmasında çıplak bir kadının resmedilmesi sanattaki değişimin işaretlerinden biri olarak kabul edilirken bazı otoriteler tarafından ise Modern sanatın başlangıç noktalarından biri olarak görülmüştür. Giorgione'nin ölümü sebebiyle tam olarak bitirilememiş olan tablo, daha sonra İtalyan ressam Titian tarafından "Urbino Venüsü” isimli başka bir çalışmada tamamlanmaya çalışılmıştır. Titian, çalışmasında Venüs olduğu düşünülen çıplak bir genç kadını, Rönesans dönemine ait bir sarayın gösterişli ortamında, bir kanepe ya da yatak üzerinde uzanmış olarak betimlemiştir. Ressamlar tarafindan birçok kez öykünme yöntemi ile alıntılanan bu eser fotoğraf yolu ile de benzer çalışmalara konu olmuştur. Fotoğrafçılar sanat tarihinin önemli çalışmalarını birçok kez kurgusal olarak yeniden canlandırarak fotoğraf tekniği ile yeniden üretmeye çalışmışlardır.

Görüldüğü üzere pastiş, geçmiş dönemlerde de günümüzde de sanatın içinde varlığını sürdürmektedir. Geçmiş dönem sanatçıları dönemlerinin imkanları doğrultusunda bu bağlamda çalışmalar üretirlerken, günümüz sanatı teknolojik gelişmeler ve yenilikler sayesinden birçok yeni çalışma biçimine olanak sağlamaktadır.

\subsection{Parodi}

Parodi genel anlamıyla alayı ve taklidi içermektedir. "Parodi; ele aldı̆̆ı yapıtın, zayıf yanlarını ortaya koymak, saldırıda bulunmak, onu gülünç duruma düşürmek, basit bir yapıya yüce bir tarzı uygulamak ya da tam tersine ciddi bir yapıtın gülünç taklidini yapmak gibi çeşitli biçimlerde ortaya çıkan bir alıntı biçimidir" (Yamaner, 2007:30-31). Parodi postmodernizm de alayı ve taklidi içermektedir. Çok ciddi bir yapıtın parodisi yapılarak, biçimin orijinali ile alay edilerek 'mizahi taklidi' yapılır. Arsitotales, parodiyi destan, trajedi, şiir gibi metin türlerinin, şiirsel bir tonda yazılan gülünç bir taklidi olarak tanımlamaktadır. "Yazınsal bağlamda, klasik dizgede oyunsal bir işlevle bir kuralı çiğneme biçimi olarak tanımlanan yansılamada gerçekleştirilen dönüştürüm işlemine karşın, yansılayan metin ile yansılanan metin arasında çok sayıda benzerlik bulmak olasıdır”. Bu dönüştürüm işlemi sırasında dönüştürülen yapıtın biçiminde bir değişiklik olmadığı için aynı zamanda bir taklit işlemi de söz konusu olmaktadır. Birçok kuramcı parodi üzerine farklı tanımlamalar yapmışlardır fakat bu tanımlamalar genellikle ortak bir görüşü içermemektedir. Baktin, pastiş ve parodiyi aynı düzlemde ele alarak biçemleştirme başlığı altında bir araya getirmiştir. Gerard Benette ise, iki kavramı birbirinden ayırarak ana metinsellikten uzaklaşarak köken metin ilişkileri üzerinden bu kavramların yapı ve işlevleri bakımından ele almıştır. Daniel Sangsue ise parodiyi, özgül bir metnin oyunsal, gülünç ya da yergisel bir dönüşümü olarak tanımlamaktadır (Aktulum, 2011:480). Tüm bu tanımlamalar ışında parodi için genel bir tanımlama yapacak olursak, bir yapıtın tam anlamıyla alaycı ya da eleştirel bir amacı olmaksızın, gülünç bir şekilde dönüştürülerek yeniden üretilmesidir. "Parodi, postmodernizmin içinde eylemsel bir olgu şeklinde var olmakta ve genelde alayı, taklidi içermektedir. Parodisi yapılan sanatsal biçimin orijinaliyle alay edilmekte ve mizah dolu bir şekilde taklidi yapılmaktadır" (Yamaner, 2007:32).

Fotoğrafçı Freddy Fabris, Rembrandt ve Da Vinci gibi Rönesans ve Barok dönemine ressamların eserlerine bir bakıma "fotoğrafla saygı" duruşu denilebilecek uygulamasında, dağınık bir otomobil tamirhanesini kullanmayı tercih etmiştir. Proje oluşumunda sanatçı, tamirhanedeki bütün mekanik araçlara klasik portrelerdeki gibi; örneğin Son Akşam Yemeği, Adem'in Yaratılışı gibi tablolardaki manzarayı hatırlatırcasına poz verdirmeyi düşünmüştür. Fakat bu fikrini yanındaki arkadaşları ile 
paylaştıktan sonra herkes projenin bir parçası olmak istediğini belirtmiş ve sanatçının Renaissance serisi doğmuş.

Sanatın, yaratıcılı̆̆ın ve estetiğin altın çağını yaşadığı Rönesans dönemine ait çalışmalarda otomobil tamircilerinin getirdiği tuhaf, düşündürücü ve eğlenceli fotoğraflar parodi yaklaşımınında güzel örneklerini oluşturmaktadır. Sanatçının bu serisi International Color Award, One Eyeland Silver Award ve APA Conceptual Award gibi birçok ödül de kazanmıştır.

\subsection{Kendine Mal Etme}

20. yüzyılın ikinci yarısında postmodernizme geçişle sanatta var olan tüm dönüşümlerin yanı sıra fotoğrafta yeniden üretim içerisinde yer alan yeni bir yaklaşımlardan bir diğeri kendine mal etmedir. Sanatta kendine mal etme var olan objeleri ya da görüntüleri küçük değişikler yaparak ya da olduğu gibi kullanarak yeniden anlamlandırıp yeni bir forma sokmak, yeni bir sanat ürünü ortaya çıarmak demektir. Fotoğrafta kendine mal etme eylemi, görüntüyü ait olduğu bir çerçeveden ve içinde bulunduğu koşullardan kopararak başka bir anlam kazanacağı farklı bir çerçeveye taşımaktadır.

Sherrie Levine, Barbara Kruger ve Richard Prince fotoğrafi kendine mal etme eylemi içinde ifade aracı olarak kullanan önemli sanatçılar arasındadır. Fotoğrafçı ve kavramsal sanatçı olan Sherrie Levine, sanat ve fotoğraf tarihinin klasikleşmiş modern figürlerinin yapıtlarını kendine mal ederek, yaratıcılığın kökeni ve cinsiyet ayrımı üzerinde durmaktadır. Sherrie Levine yapı sökümcü sanat anlayışını, 1990'larda fotoğrafi araç olarak kullanarak yapan sanatçıların başında gelmektedir. Levine, diğer sanatçıların ünlü fotoğraflarını yeniden fotoğraflayarak bunları birer orjinal eser olarak sunmayı denemiştir. Sanatçı, geleneksel ikonografik yöntemlerle girişilen analizlerin yetersizliğini vurgulamıştır. Sanatçının çalışmalarında; anlam, kişisel yaratıcılıkla oluşturulamaz, fakat kaynaklardan ve sanatçılardan elde edilen veriler ile eksiksiz olarak, tümüyle tanımlayıcı gerçek bir çağdaş kolaj gerçekleştirir, izleyici orjinal ve kopya arasında savrulan anlamı kendi okumalarıyla oluşturacaktır (Şahiner, 2013:120).

Levine, gerçekte Walker Evans'ın, yapıtındaki orjinallik niteliğiyle oyun oynamakta ve sanatın "orjinallik" geleneğiyle dalga geçmektedir. Levine, cüretkar bir tavırla ele geçirdiği imajları kullanışını kendince makul bir gerekçeye dayandırır: "Ağaçları ya da çıplakları fotoğraflamak yerine fotoğrafları fotoğraflıyorum. Fotoğraflayacağım şeye karar verirken, doğa ve kültürün sunduğu anlam ve duyarlılık ilkelerinden yararlanıyorum" (Deitcher, 1991:9).

\subsection{Gizli Alıntı}

Aşırma Aktulum'a göre; "Bir sanatçının kendi düşünsel çabasının sonucu olmayan, bir yapittan kimi bölümleri ya da bütünü ayraçlarla belirtilmeden, aşırıya varacak derecede olduğu gibi kopyalaması, sanatçının adının yerine kendi adını yazması, böylelikle bir başkasının eserini kendi eseriymiş gibi göstermesi, onu sahiplenmesi olarak tanımlanabilir" (Aktulum, 2011:103).

Gizli alıntıda başkasının ürettiği yapıt bir başkası tarafından kendine ait bir fikir gibi gösterilmektedir. Başkalarına ait fikirleri, tasarımları, emeği sahiplenme çabasıyla, kaynak göstermeden birebir taklit işlemidir. Antoine Compagnon gizli alıntıyı, makası eline alıp başka bir metinden kesilip alındığını belirtmeden yapıştırmak olarak tanımlamaktadır. Gizli alıntı yöntemi genellikle eleştirilen bir yöntem olmaktadır ve aynı zamanda hukuksal cezai bir işlemi de gerektirmektedir (Aktulum, 2011:103). Bu bağlamda en önemli örneklerden biri fotoğrafçı Annie Leibovitz' in çekmiş olduğu fotoğrafin Mehmet Turgut tarafindan yinelenmesidir.

Görüldüğü üzere Annie Leibovitz'in Angelina Jolie için kurgulayıp, çektiği fotoğraf karesi, Mehmet Turgut tarafindan küçük müdahalelerle kurgusal olarak değişime uğramıştır. Görüntüsel anlamda kullanılan nesneler, unsurlar ve figür neredeyse aynı açıdan fotografik olarak yorumlanmıştır. Annie Leibovitz'in içi su dolu bir küvette ele aldığı kompozisyonu, Mehmet Turgut süt ile değiştirmiştir. Fakat kurgusal olarak yaratılan bu fark anlamsal olarak değişmemiştir. Gizli alıntıyı taklitten ayıran en büyük özellik gizli alıntıda, alıntı yapılan çalışmanın sahibine ya da esere dair herhangi bir bilgi verilmeden çalışmanın sahiplenilmesidir. Taklit ise gerek ustalara saygı gerek sanatçının kendisini geliştirmesi kapsamında geçmiş eserlerin birebir alıntılanması işlemidir. Aradaki en önemli nokta ise taklit işleminde daima taklit edilen çalışmanın ya da eseri yaratan sanatçının ismi belirtilmelidir, belirtilmediği taktirde gizli alıntı yöntemi kapsamına girmektedir ve yasal sonuçlar doğurabilmektedir.

\section{Fotoğrafta Yeniden Üretim İçerisinde Ele Alınan Farklı Teknikler}

Günümüzde teknik yöntemlerin yanı sıra yeniden üretim içerisinde; kolaj ve fotomontaj ile kadraj içerisinde fotoğraf kullanma kavramları da farklı teknikler olarak ele alınmaktadır. 


\subsection{Kolaj ve Fotomontaj}

1900'lü yılların başında plastik sanatlar alanında doğan, daha önceden var olan yapıtlardan belli başlı unsurların alınıp yeni bir yaratı düzenine sokulması işlemidir (Aktulum, 2011:222). Sanatçı, kolaj yöntemi ile yapıtını oluştururken, çalışmasını alıntıladığı nesneye göre düzenlemektedir. Kolaj ile başka yapıtlara ait unsurların yeni bir yapıta dahil edilmesi süreci başlatılmaktadır ve bu süreçte yeniden üretim işlemine olanak sağlamaktadır. Kolaj işleminde bir bütünden unsurlar alınıp, bu unsurlar başka bir yapıtın içine katılmaktadır, yani bir kesme işlemi gerçekleşmektedir. Daha önceden oluşturulmuş var olan unsurlar kesilip alınarak yeni bir yapitta yeni bir anlama dönüştürülmektedir. Göstergeler arası alışverişlerden kolaj yöntemi “alıntı” yönteminin farklı bir türünü oluşturmaktadır. Dolayısıyla hem alıntı yapılan ilk yapıt hem de alıntı yöntemiyle ortaya çıkan farklı yapıt, yeni bir değerlendirmeyi de gerektirmektedir. Farklı unsurların kolaj yöntemiyle aynı yapıtta buluşturulması işlemi ise açı yapıt ve çoğul yapıt gibi kavramlar içinde bir çözümleme olanağı sağlamaktadır (Oskay, 2003).

İlk olarak 19. yüzyılda fotomontaj çalışmalarına rastlanmaktadır. Fakat bu dönemde bu çalışmalar çoklu baskı olarak isimlendirilmiştir. Çoklu baskı işlemi, birden fazla negatifin birleştirilmesinden oluşturulmaktadır. Oscar Gustave Rejlander, Victoria döneminin ilk çoklu baskı öncüsü ve ustası olarak kabul edilmektedir. Bu dönemde fotoğrafçılar ve ressamlar sık sık, şiir, efsane ve İncil'den faydalanmış ve sahne alıntıları yapmışlardır. Oscar Rejlander'in çoklu baskı örneği olan "Two Ways of Life" (1855) adlı fotoğrafı bu tarzda alegorik konuya iyi bir örnektir. Kraliçe Elizabeth tarafindan 10 kopya satın alınarak çalışmanın döneminde de oldukça adından söz ettirdiği görülmektedir.

Günümüzde görsel sanatların tümünde bir düzenleme tekniği olarak kullanılan kolajsa, 20. yüzyılın başlarında kübizm ile sanata girmiştir. Kübizm, sanat ortamının çok hareketli olduğu bu dönemde yeni bir biçim dili ortaya koyabilmiş, sanatçıları ve söylemleri ile gelecek akımların öncüsü olmuştur. Kübizme kadar süslemecilikte ve tekil örneklerde görülen kolaj, kübist sanatçıların uygulamalarıyla yeni bir sanat anlayışı içinde kendisine yer etmiştir. Kolaj, kübizmin nesnenin farklı konumlarını bir arada veren ve parçalanan gerçekliğin yeni bir bütünde sunumunu esas alan, gerçek nesne olan yapıştırılmış kağıt parçalarını bünyesinde barındırması nedeniyle önemli bir ifade aracı olmuştur. Farklı malzeme kullanımı, 1899 yılında Picasso tarafından çizime fotoğraf yapıștııılmasıyla başlamıș, 1908 yılında da yine çizimine müze biletini yapıştırmıştır. 1911 yılında Baraque harfleri soyut eleman olarak resme sokmuş ve ardından 1914 yılına kadar yapımına devam ettiği kağıt heykellerine başlamıştır (Lynton, 2009:74-75).

Kübizmi izleyen dada akımı başkaldıııcı, yıkıcı yapısıyla, kübizmin yıkmaya başladığı geleneksel yöntemleri sorgulamaya devam ederek yaşamın içindeki malzemeleri birleştirerek, kolaj tekniği ile birçok uygulama örnekleri vermiştir. "Dadaizmin hemen hemen her şeyi inkâr etmesi, yeni ve güçlü iletişim yöntemleri yaratmış; bunlar şiirde yeni biçimlerin kullanılması, görsel iletişimde ise kolaj ve fotomontaj gibi teknikler olmuştur. Bu tekniklerde, resimli dergilerden, eski mektuplardan, basın ilanı ve etiketlerden kesilen fotoğraflar yeni bir düzenlemeyle yapıştırılmış ve birbiriyle ilgisi olmayan bu resim ve işaret parçalarından, yeni anlamlar yaratan bağlantıların kurulduğu, genellikle kışkırtııı nitelikte düzenlemeler oluşturulmuştur" (Bektaş, 1992:46-47).

20. yüzyılda değişen sanat anlayışı ile birlikte üretilen fotomontaj çalışmaları da farklılaşmaya başlamış ve yeni sanat anlayışlarını destekleyen görüntüler olarak boy göstermiştir. 21. yüzyıla günümüze gelindiğinde dijitalleşmeyle birlikte geçmişte var olan tüm yeniden üretim yaklaşımları ve teknikleri postmodernist bir yaklaşımla daha da gelişip yaygınlaşmaktadır. Dijitalleşme ile fotomontaj tekniği bilgisayar ortamında üretilme firsatı bulmakta, geçmişin farklı sanat dallarındaki kült eserleri bugün sanatta hala konu edilmektedir.

21. yüzyılda kolaj ve fotomontaj tekniğini çalışmalarında ustaca kullanan fotoğrafçıların en önemlilerinden birisi Fransız fotoğrafçı Gilbert Garcin'dir. Garcin, çalışmalarında mizahi bir yaklaşım ve sürrealist bir üslupla yaşlılık, hayatın karanlığı, tekrarları ve kısır döngüsü gibi konuları ele almaktadır. Siyah beyaz çalışmalar üretmektedir. Kurguladığı sahnelerde kum, taş, çamur ve ip gibi gerçek objeler kullanarak gerçek gölgeler oluşturmaktadır. Objelerin ölçekleriyle oynayarak, gerçekliğin yerini alan göz yanılsamaları yaratmaktadır.

Türk fotoğraf tarihinde deneysel kolaj çalışmaları üreten en başarılı sanatçılar arasında kuşkusuz önemli isimlerin başında Şahin Kaygun gelmektedir. Kaygun'un fotoğraf anlayışında oldukça fazla görsel sanatlardan yararlanma vardır. Teknik olarak silme, kazıma, boyama, kolaj ve fotomontaj gibi teknikleri fotoğraf çalışmalarında kullanmıştır. Şahin Kaygun, fotoğraf "çekmediğini”, fotoğraf "yaptığını" belirtmiştir. O'na göre fotoğraf; makinanın sunduğu hazır görüntüyü kişisel bir vizyona dönüştürecek olanakların araştırıldığı bir alandır. Sanatın genelinde olan müdahale ya da değiştiricilik, Kaygun'un fotoğraflarında iyice yansımasını bulmuştur. Kendisi de çalışmalarında sınırsız müdahale yöntemleri uygulamış, bu nedenle de 1980 'li yılların sonunda yaptığ 1 Polaroid fotoğrafları ve 1990'lı yılların başında sergilediği resim-fotoğraf bileşimi Foto pentür çalışmaları büyük tartışmalar yaratmıştır.

19 | P a g e 
Kaygun; akrilik boya kullanarak fotoğraf üzerine resim yapar. Bu basit ve bilinen teknik yöntemle Kaygun'un kolajları, fantastik kurguları, simgesel anlatımları biraraya gelince de resim-fotoğraf karışımı yapıtları ortaya çıkar. Foto pentürleri, bütünüyle fotoğraf teknikleri kullanılarak gerçekleştirilmiştir. Kullanılan görsel öğelerin büyük bir bölümü, insan gövdeleri, oyuncak bebekler, deniz kabukları, heykeller vs. hep fotoğrafik görünümlerdedir.

Polaroid fotoğraf çalışmaları, her şeyden önce küçük formatın büyük başarısını simgelemektedir. Polaroid karta doğuş anında müdahaleler, çizgi ve renk düzenlemeleri bir duygu saptaması olarak tarihe geçmiştir. Sanatçının polaroid deneyini, değişik dünyasını anlatacak bir üslup arayışı olarak değerlendirmek gerekir. Polaroid fotoğraflarında yalın, renkçi bir tavır egemendir. Polaroid'in, dışarıdan müdahalelerle kişisel bir görsellik kalitesi kazandığını kanıtlayan işler, o zamana kadar bu türü küçümsemiş olanları şaşırtmıştır. Bir tür "şipşak" fotoğraf olarak tanımlanan ve salt aceleci turistlerin lüksüne cevap vermekten öte bir değer taşımadığı sanılan polaroid fotoğraf, Şahin Kaygun'un usta ellerinde yeni bir anlam kazanmıştır. Polaroid çalışmalarıyla Şahin Kaygun, sanatçının teknolojinin emrinde değil, teknolojinin sanatçının emrinde kullanılması gereken bir araç olduğunu kanıtlamıştır.

Son dönem Türk fotoğrafina bakıldığında çalışmalarında fotomontaj tekniğini ustaca kullanan bir diğer sanatçı Murat Germen'dir. Sanatçının "Muta-morfoz" serisi, güzel bir fotomontaj ve manipülasyon örneğidir. Sanatçı; bu seride, çektiği panoramik fotoğrafları belirli bir algoritmaya göre sıkıştırdığını belirtmiştir. Şehir bu fotoğraflarda iç içe geçmiş yapılarıyla tüm sıkışıklığı ve yoğunluğuyla karşımıza çıkmaktadır. Sanatçı; fotoğraflar üzerinden yaptığı bu manipülasyonların aslında şehrin gerçeği olduğunu vurgulamaktadır. Sanatçı, bu seride, kentsel dönüşüm projesinin getirisinin yüksek oluşunun, projeye dahil olan herkesi, doğayı ve binaların kalitesini düşünmekten alıkoyduğuna dikkat çekmektedir. "İnsanlar bu binaların içinde nasıl yaşayacaklar, açık alanlar yüksek binalar için nasıl bir çevre oluşturabilir?" gibi soruların devre dışı bırakıldığını vurgulamaktadır.

Sonuç olarak yapıtlarda farklı işlevlerde ve farklı görünümlerde karşımıza çıkan kolajlar ve fotomontajlar, farklı unsurları yapıta sokmak için bir yoldur. Yapıtlardan alıntı yapılan unsurlar yeni bir bağlamda yinelenerek göstergeler arası yaklaşım için geçmişte ve günümüzde uygulanabilir bir yöntem olarak kullanılmaktadır.

\subsection{Kadraj İçerisinde Fotoğraf Kullanma}

Fotoğrafta yeniden üretim içerisinde yer alan bir diğer yöntem fotoğrafların kadraj içinde kullanılarak yeni görüntülerin elde edilmesidir. Günümüz popüler kültürü içinde özellikle sosyal medyada bu yöntem ile çekilmiş fotoğraflarla sıklıkla karşılaşılsa da fotoğrafin kadraj içerisinde kullanımını sanatsal bir üslup olarak benimseyen ilk sanatçı Kenneth Josephson'dur.

1960'lardan bu yana genellikle siyah-beyaz çalışmalar üreten fotoğrafçı Kenneth Josephson, ilk çalışmalarında fotoğrafçı Harry Callahan ve Aaron Siskind' ten etkilenmiştir. İlerleyen dönemlerde ürettiği çalışmalarda fotoğraf içinde fotoğraf kullanması ile fotoğrafta gerçeklik ve yanılsama kavramlarını yorumlamıştır. Bir mekanın gerçekliğini sorgulamada fotoğrafın kendisini kullanmıştır (Artspace, 2015).

Fotoğraf içinde fotoğraf kullanımı özellikle zıtlıkların vurgulandığı belgesel çalışmalarda da kullanılan bir yöntemdir. Kadraj içerisinde fotoğraf kullanımını, kullanan bir diğer sanatçı Sarah Moon' dur. Moon, "Kırmızı Başlıklı Kız" serisinde yer alan aşağıdaki karede fotoğrafik atmosfer yaratmada kadraj içinde fotoğraf kullanımının başarılı bir örneğine imza atmıştır.

Görüldüğü gibi çalışmalarda kadraj içerisinde fotoğraf kullanma, fotoğrafa yeni anlamlar katma ve farklı unsurları yapıta sokmak için bir yoldur. Kadraj içerisinde fotoğraf kullanımı bir fotoğrafa farklı bir çerçevede yeni bir anlam katabilmektedir. Bu yönü ile geçmişte ve günümüzde yeniden üretim içinde uygulanabilir bir yöntem olarak görülmektedir.

\section{Sonuç}

Farklı sanat disiplinleriyle sürekli alışveriş halinde olan ve bu doğrultuda ilerleyen fotoğraf sanatında, özellikle postmodern öğreti içerisinde ortaya çıkan yeni çalışma biçimleri ile çeşitli örnekler üretilmiştir. Fotoğraf, bir sanat dalı olarak gelişirken aynı zamanda başka sanat dalları ve akımlarını da etkisi altına almıştır. Çağdaş sanatın amaçlarından birisi olan "sanat ile hayat ayrımını ortadan kaldırma" fikri ile fotoğrafin gerçeklikle olan bağı düşünüldüğünde, fotoğraf kendini çağdaş sanat içinde önemli bir araç konumuna getirmiştir.

Modernizmden önce geçmişi belgeleme, gerçeği yansıtma, gibi kalıplara bağlı fotoğraf sanatında modernizmle birlikte bu kalıplardan sıyrılarak daha özgür ve soyut çalışmaların yapıldığı yapıtlar üretilmeye başlanmıştır. Postmodernizmle birlikte eskinin yeniden üretimi oldukça sık başvurulan bir yöntem olarak kullanılmıştır. Sanatçılar yapıtlarında daha önceden ortaya çıkan akımlardan alıntılar yaparak, yeni bir anlayış benimsemişlerdir. Bu anlayış doğrultusunda alıntı, parodi, pastij, gizli alıntı gibi

20 | P a g e 
göstergeler arası yaklaşımlar ele alınmış; montaj, fotomontaj ve kadraj içerisinde fotoğraf kullanma gibi yöntemler kullanılmıştır. Teknik bir süreçten daha fazlası olduğunu kanıtlayan fotoğraf, sanat alanına etki ederek, resim, sinema, edebiyat gibi disiplinlerle etkileşimini sürdürmüştür.

Sonuç olarak yeniden üretimin 19. yüzyıldan beri fotoğrafın içerisinde yer aldığı görülmüştür. Bu doğrultuda yeniden üretiminin zamanla farklı bakış açılarını da beraberinde getirdiği gözlemlenmiştir. Yeniden üretim, bir sanat eserine yeni bir açıdan bakma olanağı sağlamakta ve yeniden üretilen eserin yeni bir gözle değerlendirilmesinin önünü açmaktadır. Böylelikle geçmiş dönemlere ait eserler alıntılanarak yeni bir forma uygulanabilmekte, yeni bir anlama dönüştürülebilmektedir.

\section{Kaynakça}

[1] Aktulum, K. (2011), “Metinler Arasılık / Göstergeler Arasılık, Kanguru Yayınları, Ankara.

[2] Bektaş, D. (1992), “Çăgdaş Grafik Tasarımın Gelişimi”, Yky Yayınları, İstanbul.

[3] Deitcher, D. (1991), "Sherrie Levine: Rules Of The Game”, (Ed.) Sherrie Levine, Kunsthalle Zurich, Paris.

[4] Eczacıbaşı Yayınları, (1997), "Eczacıbaşı Sanat Ansiklopedisi”, Cilt:3, Yapı Endüstri Merkezi Yayınları, Ankara.

[5] Grundberg, A. (2002), "Modernist Akım Sürecinde Fotoğraf ve Sanat”, (Çev.) Kemal Atakay, Sanat Dünyamı, Sayı: 84, Yaz, İstanbul.

[6] Lynton, N. (2009), “Modern Sanatın Öyküsü”, (Çev.) Sadi Öziş, Remzi Kitabevi, İstanbul.

[7] Oskay, A. (2003), “Kübist Kolajlar”, Journal Of İstanbul Kültür University, Sayı:3, İstanbul.

[8] Şahiner, R. (2013), “Sanatta Postmodern Kırılmalar”, Ütopya Yayınevi, Ankara.

[9] Topoyan, M. (2005), "Yeniden Üretim Sistemleri İçin Sürdürülebilir Ürün Tasarımlarının Oluşturulması" V. Ulusal Üretim Araştırmaları Sempozyumu, İstanbul Ticaret Üniversitesi, İstanbul.

[10] Yamaner, G. (2007), “Postmodernizm ve Sanat”, Alg1 Yayıncılık, Ankara. 